\title{
Modified Composite Based on Magnetite and Polyvinyl Alcohol: Synthesis, Characterization, and Degradation Studies of the Methyl Orange Dye from Synthetic Wastewater
}

\author{
Cristina Modrogan ${ }^{1}$, Simona Căprărescu ${ }^{2, *}$, Annette Madelene Dăncilă ${ }^{1}$, Oanamari Daniela Orbuleț ${ }^{1}$, \\ Alexandru Mihai Grumezescu ${ }^{3,4,5}$ D, Violeta Purcar ${ }^{6} \mathbb{D}$, Valentin Raditoiu ${ }^{6}$ and Radu Claudiu Fierascu ${ }^{3,6} \mathbb{D}^{\mathbb{D}}$
}

1 Department of Analytical Chemistry and Environmental Engineering, Faculty of Applied Chemistry and Materials Science, University Politehnica of Bucharest, Ghe. Polizu Street No 1-7, 011061 Bucharest, Romania; cristina.modrogan@upb.ro (C.M.); annette.dancila@upb.ro (A.M.D.); oanamari.orbulet@upb.ro (O.D.O.)

2 Inorganic Chemistry, Physical Chemistry and Electrochemistry Department, Faculty of Applied Chemistry and Materials Science, University Politehnica of Bucharest, Ghe. Polizu Street No 1-7, 011061 Bucharest, Romania

3 Department of Science and Engineering of Oxide Materials and Nanomaterials, Faculty of Applied Chemistry and Materials Science, University Politehnica of Bucharest, Ghe. Polizu Street No 1-7, 011061 Bucharest, Romania; alexandru.grumezescu@upb.ro (A.M.G.); fierascu.radu@icechim.ro (R.C.F.)

4 Research Institute of the University of Bucharest-ICUB, University of Bucharest, 050657 Bucharest, Romania

check for updates

Citation: Modrogan, C.; Căprărescu, S.; Dăncilă, A.M.; Orbuleț, O.D.; Grumezescu, A.M.; Purcar, V.; Raditoiu, V.; Fierascu, R.C. Modified Composite Based on Magnetite and Polyvinyl Alcohol: Synthesis, Characterization, and Degradation Studies of the Methyl Orange Dye from Synthetic Wastewater. Polymers 2021, 13, 3911. https://doi.org/ $10.3390 /$ polym 13223911

Academic Editors: George Z. Kyzas and Tansir Ahamad

Received: 23 October 2021

Accepted: 10 November 2021

Published: 12 November 2021

Publisher's Note: MDPI stays neutral with regard to jurisdictional claims in published maps and institutional affiliations.

Copyright: (c) 2021 by the authors. Licensee MDPI, Basel, Switzerland. This article is an open access article distributed under the terms and conditions of the Creative Commons Attribution (CC BY) license (https:// creativecommons.org/licenses/by/ $4.0 /)$.
5 Academy of Romanian Scientists, Ilfov No. 3, 50044 Bucharest, Romania

6 National Institute for Research and Development in Chemistry and Petrochemistry-ICECHIM, Splaiul Independentei, No. 202, 060021 Bucharest, Romania; violeta.purcar@icechim.ro (V.P.); vraditoiu@yahoo.com (V.R.)

* Correspondence: simona.caprarescu@upb.ro

\begin{abstract}
The goal of the present paper was to synthesize, characterize, and evaluate the performance of the modified composite based on magnetite $\left(\mathrm{Fe}_{3} \mathrm{O}_{4}\right)$ and polyvinyl alcohol (PVA). The obtained composite was used to degrade Methyl Orange dye from synthetic wastewater by a laboratory photocatalytic reactor. Various parameters of the photodegradation process were tested: composite dosage, amount of hydrogen peroxide $\left(\mathrm{H}_{2} \mathrm{O}_{2}\right)$, and $\mathrm{pH}$. The composite was characterized by Fourier Transform Infrared (FTIR) Spectroscopy, X-ray Diffraction (XRD), and Scanning Electron Microscopy (SEM). The degradation experiments indicated that the complete dye decolorization depended on the amount of $\mathrm{H}_{2} \mathrm{O}_{2}$. In addition, the $\mathrm{H}_{2} \mathrm{O}_{2}$ could accelerate Methyl Orange degradation to more highly oxidized intermediates in the presence of UV light (99.35\%). The results suggested that the obtained modified composite could be used to treat wastewater containing various types of dyes.
\end{abstract}

Keywords: modified composite; magnetite; polyvinyl alcohol; methyl orange; degradation; wastewater

\section{Introduction}

Currently, the elimination of harmful industrial dyes from wastewater is of utmost interest, as the quality of drinking water in the world is steadily declining. As these pollutants discharged into the water are largely constituent elements of various effluents from various industries (e.g., pharmaceutical, cosmetic, and food production), it is necessary to use advanced effluent treatment methods before discharging them into the environment $[1,2]$. Industries that produce textiles, paper, plastics, leather, nutriments, and cosmetic products use various dyes widely $[1,3,4]$. Dye-containing effluents resulting from these types of industries are released into water, and this action constitutes a substantial threat to aquatic life, as well as to the environment $[3,5]$. The water-soluble azo dye Methyl Orange has a highly carcinogenic risk factor and is extensively used in textile industries, manufacturing printing paper, and research laboratories. Methyl Orange has the capacity of also being metabolized into aromatic amines by intestinal microorganisms [3]. This dye, which is 
difficult to eliminate from aqueous solutions by common water purification/treatment methods because of its solubility in water, is also stable, with a low biodegradability [5].

In recent years, advanced oxidation processes (AOPs) $[1,3,6]$ have attracted greater interest in the treatment of wastewater that contains dyes, in comparison with other methods such as ozonation, biodegradation, chlorination, and biological methods [1-3], due to its advantages: high efficiency, total destruction of organic pollutants using active photocatalysts in a few hours at room temperature, and cost-effectiveness [7-10]. Among the AOPs, the photodegradation process of organic dyes using composites based on unmodified or modified magnetite $\left(\mathrm{Fe}_{2} \mathrm{O}_{3}\right)$ has been applied for the degradation of the different dyes (e.g., Acid Red73 [8], Methylene Blue [9-11], Malachite green [12], Crystal Violet [13]). Golshan et al. [3] found that the synthesized magnetite hydroxyapatite nanoparticles $\left(\mathrm{Fe}_{3} \mathrm{O}_{4} @ \mathrm{HAP}\right)$ had a good performance in the degradation of Acid Red73. The results showed that the degradation efficiency of the dye was around $97 \%$ under UV irradiation, for $1 \mathrm{~h}$. Chen et al. [8] reported that the $\mathrm{Fe}_{3} \mathrm{O}_{4} / \mathrm{Ag}_{6} \mathrm{Si}_{2} \mathrm{O}_{7}$ composites, fabricated by the precipitation process, can be used to remove Methylene blue dye from water under simulated visible light. They found that the removal efficiency of dye was higher (98\%). Guidolin et al. [10] indicated that the magnetite nanoparticles can be used to degrade Methylene blue dye from a simulated aqueous solution. The results showed that the most effective color removal of $93.4 \%$ was obtained when a higher concentration of nanoparticles of $2250 \mathrm{mg} \cdot \mathrm{L}^{-1}$ was used in $210 \mathrm{~min}$. Rivera et al. [11] studied the Methylene blue (MB) dye degradation using $\mathrm{Fe}_{3} \mathrm{O}_{4}$ nanoparticles by the Fenton-Like process. They found that a $100 \%$ color degradation was obtained for $2 \mathrm{~g} \cdot \mathrm{L}^{-1}$ of $\mathrm{Fe}_{3} \mathrm{O}_{4}$ nanoparticles and a concentration of $100 \mathrm{mg} \mathrm{MB} / \mathrm{L}$ at $\mathrm{pH}$ 3.5. Arifin et al. [12] synthesized $\mathrm{Fe}_{3} \mathrm{O}_{4} / \mathrm{TiO}_{2} / \mathrm{CuO}$ nanocomposites for the degradation of Malachite green from aqueous solution under UV and visible light irradiation. The results suggested that the photocatalytic activity of nanocomposites was enhanced under visible light irradiation.

The synthesis of $\mathrm{Fe}_{3} \mathrm{O}_{4}$ nanoparticles containing polymers (e.g., poly(vinyl alcohol) (PVA), poly(vinylpyrrolidone) (PVP)) has rarely been reported in the literature [14-16]. Mahmoudi et al. [14] prepared magnetite nanorods using polyvinyl alcohol (PVA) using the co-precipitation method. They reported that the formation of magnetic beads was favored when a higher concentration of PVA (polymer/iron mass ratio of 5) was used. Seo et al. [15] reported the synthesis of $\mathrm{Fe}_{3} \mathrm{O}_{4}$ using PVP. They reported that PVP protects the $\mathrm{Fe}_{3} \mathrm{O}_{4}$ powder from further oxidation and prevents the agglomeration of the $\mathrm{Fe}_{3} \mathrm{O}_{4}$. Usawattanakul et al. [16] prepared the nanocomposite film of poly(vinyl alcohol) (PVA) incorporated with bacterial cellulose nanocrystals and magnetite nanoparticles $\left(\mathrm{Fe}_{3} \mathrm{O}_{4}\right)$ by the in situ synthesis technique using chemical coprecipitation. Their study showed that the prepared film, due to its high hydrophilicity, can be applied in diverse fields for the adsorption of various pollutants.

In this work, we prepared unmodified and modified composites based on magnetite $\left(\mathrm{Fe}_{3} \mathrm{O}_{4}\right)$ and polyvinyl alcohol (PVA) by the co-precipitation method. These composites were prepared for the removal of Methyl Orange dye from synthetic wastewater using a laboratory photocatalytic reactor under various conditions. The composite was characterized by Fourier Transform Infrared (FTIR) Spectroscopy, X-ray Diffraction (XRD), and Scanning Electron Microscopy (SEM). Influencing factors regarding photocatalytic degradation such as composite dosage, amount of hydrogen peroxide $\left(\mathrm{H}_{2} \mathrm{O}_{2}\right)$, and $\mathrm{pH}$ value were also investigated. In addition, the effect of $\mathrm{UV}$ irradiation on the $\mathrm{Fe}_{3} \mathrm{O}_{4} / \mathrm{PVA}$ composite was studied.

\section{Experimental Methods}

\subsection{Materials and Methods}

Ferrous sulfate hexahydrate $\left.\left(\mathrm{Fe}\left(\mathrm{SO}_{4}\right) \cdot 6 \mathrm{H}_{2} \mathrm{O}\right)\right)$ and ferric chloride $\left(\mathrm{FeCl}_{3}\right)$ were purchased from Chimopar (Chimopar SRL, Bucharest, Romania). Ammonia $\left(\mathrm{NH}_{3}\right)$ and poly(vinyl alcohol) (PVA) were purchased from Sigma Aldrich (Merck KGaA, Darmstadt, Germany) without additional purification. Hydrogen peroxide $\left(\mathrm{H}_{2} \mathrm{O}_{2}\right)$, sulfuric 
acid $\left(\mathrm{H}_{2} \mathrm{SO}_{4}\right)$, and manganese dioxide $\left(\mathrm{MnO}_{2}\right)$ were purchased from Merck (Merck KGaA, Darmstadt, Germany). All reagents that were used were of analytical grade. The distilled water was also used in this study to prepare the aqueous solution of dye.

Methyl Orange powder (anionic, water-soluble azo dye) was purchased from Sigma Aldrich (Merck KGaA, Darmstadt, Germany) and was utilized without any additional purification. The stock solution of Methyl Orange was prepared by dissolving powder of Methyl Orange in deionized water at room temperature $\left(23 \pm 2{ }^{\circ} \mathrm{C}\right)$ to obtain a solution concentration of $10 \times 10^{-4} \mathrm{~mol} \cdot \mathrm{L}^{-1}$. The working solution was prepared by diluting the stock solution with deionized water $\left(5 \times 10^{-4} \mathrm{~mol} \cdot \mathrm{L}^{-1}\right)$ and sulfuric acid $\left(\mathrm{H}_{2} \mathrm{SO}_{4}\right)$. The sulfuric acid was used to adjust the $\mathrm{pH}$ of the solution at 3, measured using a $\mathrm{pH}$-meter JKPH009 (Shanghai Jingxue Science Apparatus Co., Ltd., Shanghai, China). An amount of the concentrations above was utilized to calibrate a curve of absorbance against concentration at a prearranged wavelength at a maximum absorbance $\lambda=464 \mathrm{~nm}$ utilizing a UV-Visible spectrophotometer Shimadzu 9100 (Shimadzu Scientific Instruments, Columbia, SC, USA). The sensitivity and accuracy of the machine were maximally improved using measurements of absorbance at a wavelength. From this calibration curve, we could establish the exact concentrations.

\subsection{Synthesis of the Composite}

Magnetite $\left(\mathrm{Fe}_{3} \mathrm{O}_{4}\right)$ was obtained directly by the precipitation reaction between prepared solutions of $\mathrm{FeSO}_{4} 0.2 \mathrm{~mol} \cdot \mathrm{L}^{-1}$ and of $\mathrm{FeCl}_{3} 0.2 \mathrm{~mol} \cdot \mathrm{L}^{-1}$ with concentrated ammonia $\left(\mathrm{NH}_{3} 25 \%\right)$ without heat treatment.

The $\mathrm{Fe}_{3} \mathrm{O}_{4}$ /PVA composite was prepared by the following procedure: in a Berzelius beaker, the necessary volumes (in stoichiometric quantities of $200 \mathrm{~mL}$ ) of the prepared solutions $\left(\mathrm{FeSO}_{4}\right.$ and $\left.\mathrm{FeCl}_{3}\right)$ were added in order to obtain $3 \times 10^{-3} \mathrm{~g}$ of $\mathrm{Fe}_{3} \mathrm{O}_{4}$. Under continuous mechanical stirring (400 rpm) (RSLAB 13 PRO 20 Digital Mechanical Stirrer, Distribution Account Manager Laboratory, Telecomed, Iasi, Romania; IKA ${ }^{\circledR}$-Werke GmbH \& Co., KG, Deutschland, Germany), the concentrated ammonia (15 mL) was added over the obtained solution. Afterward, the mixture was stirred for another $20 \mathrm{~min}$ (at $400 \mathrm{rpm})$ until a black precipitate was obtained. The solution above the precipitate (immobilized with a magnet placed under the beaker) was decanted. The obtained precipitate was washed three times with $50 \mathrm{~mL}$ of distilled water until the chloride ions were completely removed. Then, a PVA solution (5\%) was added over the mix of precipitate formed and was magnetically stirred together at $400 \mathrm{rpm}$ for $20 \mathrm{~min}$ at room temperature $\left(23 \pm 2{ }^{\circ} \mathrm{C}\right)$. After the mixing time had elapsed, the solution was filtered and rinsed with distilled water and was then transferred to a watch bottle (weighed beforehand) for drying. The formed precipitate was slowly heated at $100^{\circ} \mathrm{C}$, using an oven (Multilab ML-LE 15/11, Distribution Account Manager Laboratory, Analytical Equipment MultiLab SRL Romania, Bucharest; IKA $^{\circledR}$-Werke GmbH \& Co., KG, Deutschland, Germany). After gelling, the temperature was increased to $150{ }^{\circ} \mathrm{C}$ and the precipitate was heated for another $4 \mathrm{~h}$ using the oven in order to obtain the $\mathrm{Fe}_{3} \mathrm{O}_{4}$ / PVA composite. The PVA was used for the preparation of $\mathrm{Fe}_{3} \mathrm{O}_{4} /$ PVA (modified composite), because the PVA molecules are rich in $\mathrm{OH}^{-}$functional groups, which enable them to participate in the formation of magnetic beads.

The schematic preparation of $\mathrm{Fe}_{3} \mathrm{O}_{4}$ / PVA (modified composite) is illustrated in Figure 1.

The obtained composites $\left(\mathrm{Fe}_{3} \mathrm{O}_{4}\right.$ andFe $\left.\mathrm{O}_{4} / \mathrm{PVA}\right)$ were crushed before being characterized and used for the photocatalytic tests.

\subsection{Photocatalytic Experimental Procedure}

The experiments were performed in a laboratory installation using a photocatalytic reactor shown in Figure 2. The photocatalytic reactor had the following dimensions: inner diameter of the reactor, $80 \mathrm{~mm}$; outer diameter of quartz tube, $35 \mathrm{~mm}$; intertubular distance (irradiation), $23 \mathrm{~mm}$. The photocatalytic reactor had the following characteristics: useful volume (reaction), $1.5 \mathrm{~L}$; total solution volume, $2 \mathrm{~L}$; pump flow, $1 \mathrm{~L} \cdot \mathrm{min}^{-1}$; contact time (when recirculating), $1.5 \mathrm{~min}$. 


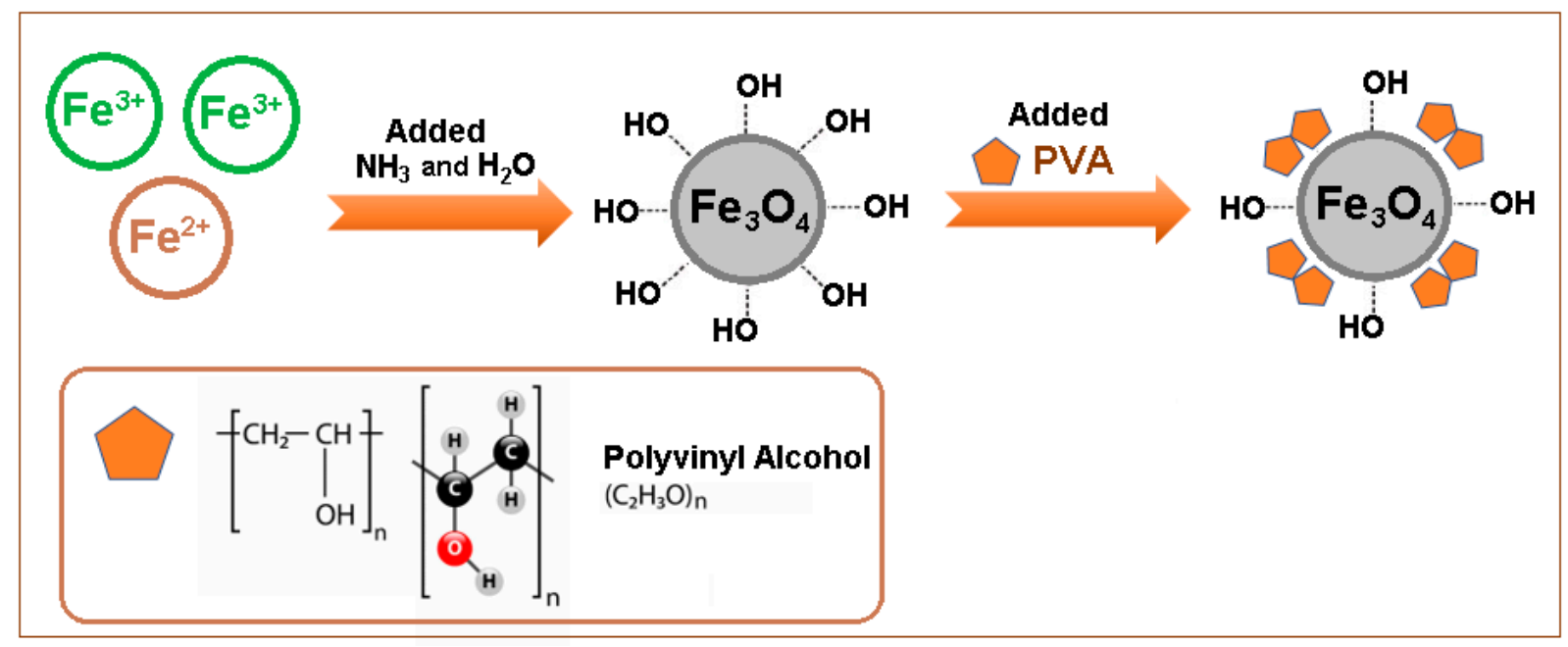

Figure 1. Schematic representation of the preparation of $\mathrm{Fe}_{3} \mathrm{O}_{4} / \mathrm{PVA}$ (modified composite).

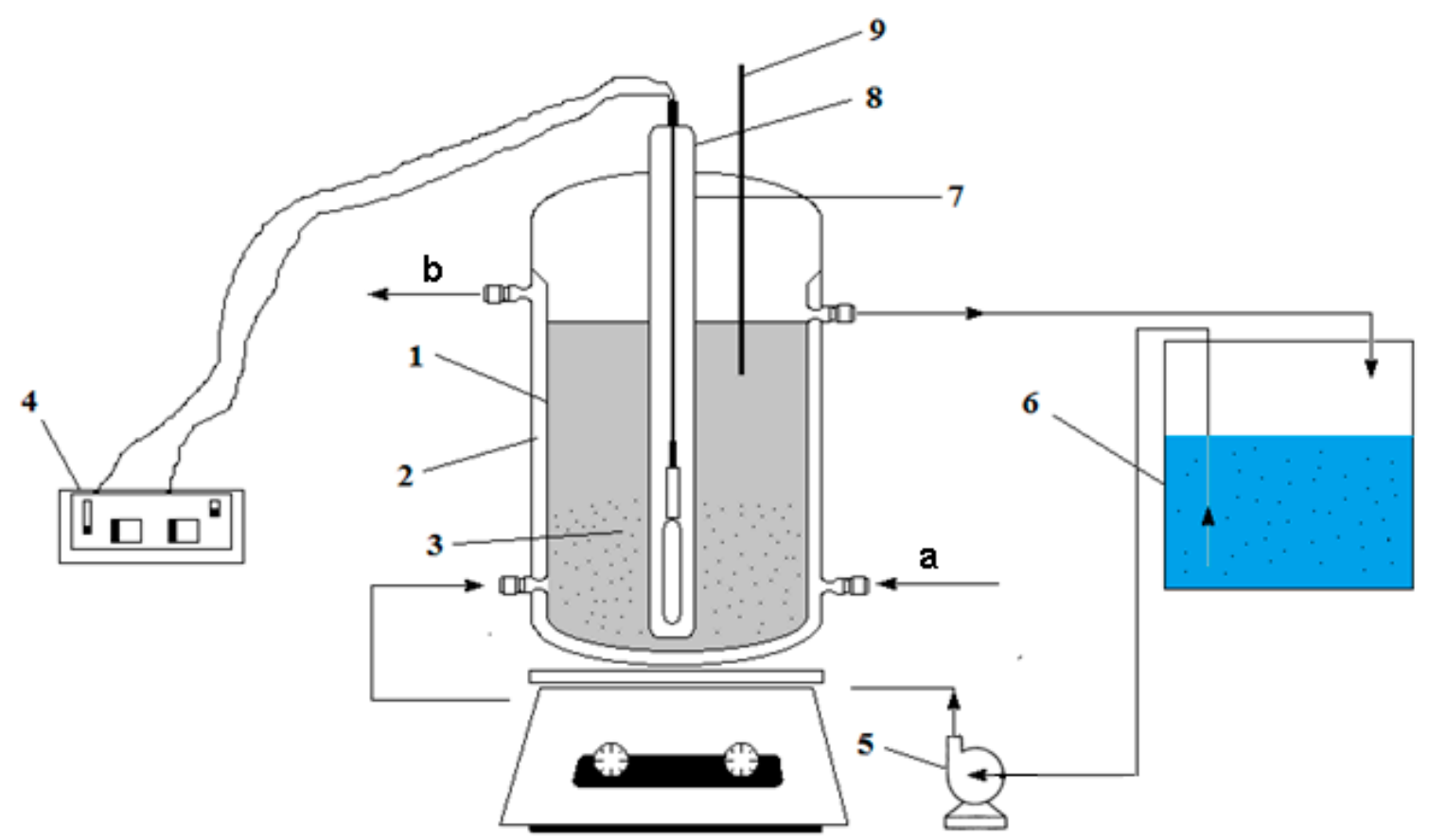

Figure 2. Laboratory installation composed of the following elements: 1-photocatalytic reactor; 2-cooling jacket (a, b); 3- $\mathrm{Fe}_{3} \mathrm{O}_{4}$ or $\mathrm{Fe}_{3} \mathrm{O}_{4}$ /PVA (modified composite); 4-UV lamp source; 5-recirculation pump; 6-recirculation reservoir; 7-UV lamp; 8-quartz tube; 9-thermometer.

The degradation of the organic compounds was performed in a laboratory installation with continuous recirculation, using a cylindrical reactor with reaction space (1) with a jacket on which the cooling water flowed (2). The photocatalytic reactor, composed of a UV radiation generator (4), of the $\mathrm{Hg}$ vapor quartz lamp type (8) was positioned axially centrally in a quartz tube to form an annular space reaction (7). $\mathrm{Fe}_{3} \mathrm{O}_{4}$ or $\mathrm{Fe}_{3} \mathrm{O}_{4} / \mathrm{PVA}$ (3) was inserted around the quartz tube. The wastewater-containing dye was introduced into the reactor from a tank (6) by means of a pump (5). The working temperature of synthetic wastewater was maintained constant at $20^{\circ} \mathrm{C}$ using a thermometer (9).

The samples were analyzed at a wavelength of $464 \mathrm{~nm}$ using a UV-Vis spectrophotometer (Shimadzu 9100, Shimadzu Scientific Instruments, Columbia, SC, USA). The samples gathered from the reactor at distinct reaction times were stabilized through the amount of $\mathrm{MnO}_{2}$ addition for fast decomposition of the unreacted $\mathrm{H}_{2} \mathrm{O}_{2}$. The $\mathrm{pH}$ was measured using a $\mathrm{pH}$ meter. 
The tests on the degradation of the organic compounds from prepared wastewater were realized at $20{ }^{\circ} \mathrm{C}$ utilizing a photo-assisted procedure $\left(\mathrm{H}_{2} \mathrm{O}_{2}+\mathrm{UV}\right)$. The experiments were conducted only in the presence of the $\mathrm{Fe}_{3} \mathrm{O}_{4} / \mathrm{PVA}$, to show the effect of PVA incorporated into $\mathrm{Fe}_{3} \mathrm{O}_{4}$.

\subsection{Characterization of the Composites}

FTIR spectroscopy was used to highlight the formation of magnetite in the synthesized samples. FTIR spectra were recorded using an FTIR spectrometer (Jasco FTIR 6300, JASCO Int. Co., Ltd., Tokyo, Japan) equipped with a Golden Gate Specac ATR (KRS5 lens), in the range of 4000-400 $\mathrm{cm}^{-1}$ (32 scans for each point at a spectral resolution of $4 \mathrm{~cm}^{-1}$ ). The deconvolution of the FTIR spectra was carried using the Jasco spectrum analysis software program (Spectra Manager II software from Jasco Inc., Tokyo, Japan).

The evaluation of the phase composition of the samples was performed using X-ray diffraction analyses, with a Rigaku SmartLab (Rigaku Corp., Tokyo, Japan), operated at $45 \mathrm{kV}$ and $200 \mathrm{~mA}$, with $\mathrm{CuK} \alpha$ radiation (1.54059 $\mathrm{A}$ ), working in parallel beam configuration $(2 \theta / \theta$ scan mode), with the diffractograms being recorded in the range of 5-90 $(2 \theta)$. The individual components were identified using the Rigaku Data Analysis Software PDXL 2 database provided by ICDD.

To investigate the morphology and dimensions of the nanostructured thin layers (obtained composites), the samples were sectioned using a diamond disc placed on a support and were introduced into an FEI Electron Microscope (SEM) (Hillsboro, OR, USA). The obtained images were recorded using secondary electron beams at an energy of $30 \mathrm{kV}$.

\section{Results and Discussion}

\subsection{Characterization of Composites}

To confirm the formation of the $\mathrm{Fe}_{3} \mathrm{O}_{4}$, the original and modified magnetite $\left(\mathrm{Fe}_{3} \mathrm{O}_{4} / \mathrm{PVA}\right)$ were analyzed using FTIR spectroscopy. The FTIR spectra of samples are shown in Figure 3.

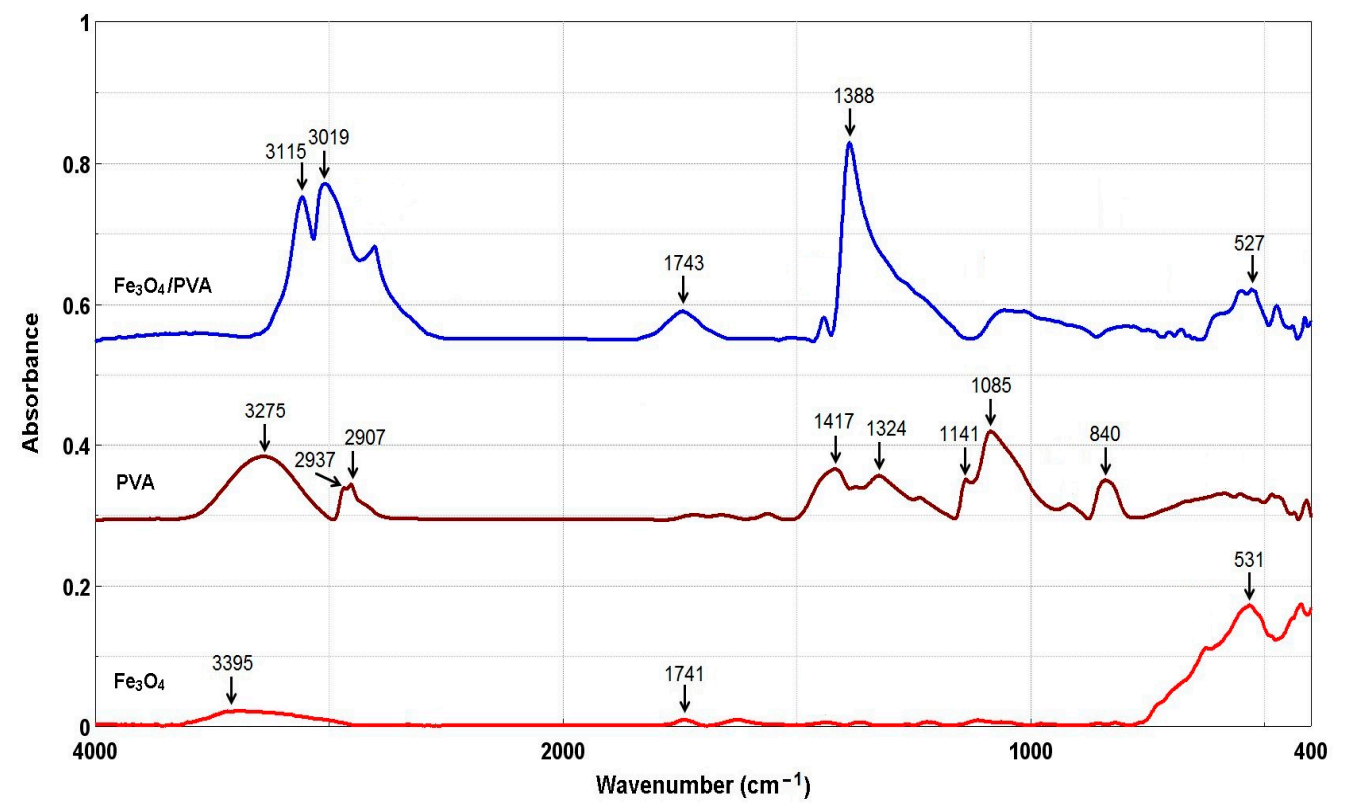

Figure 3. FTIR spectra of $\mathrm{Fe}_{3} \mathrm{O}_{4}, \mathrm{PVA}$, and $\mathrm{Fe}_{3} \mathrm{O}_{4} /$ PVA.

From Figure 3, for samples $\mathrm{Fe}_{3} \mathrm{O}_{4}$ and $\mathrm{Fe}_{3} \mathrm{O}_{4} / \mathrm{PVA}$, the presence of a peak at $\sim 530 \mathrm{~cm}^{-1}$ can be seen, which confirms the stretching vibrations of the Fe-O bonds [17-19]. The peaks detected at $1388 \mathrm{~cm}^{-1}\left(\mathrm{Fe}_{3} \mathrm{O}_{4} / \mathrm{PVA}\right)$ and $1324 \mathrm{~cm}^{-1}$ (PVA) are related to methylene stretching [16,19-22]. The peak at $3275 \mathrm{~cm}^{-1}$ observed in PVA is ascribed to the bonded hydroxyl (O-H stretching) vibration. The absorption peaks at $2937 \mathrm{~cm}^{-1}$ and $2907 \mathrm{~cm}^{-1}$ are assigned to $\mathrm{C}-\mathrm{H}$ asymmetric stretching [19-21]. The peaks observed at $1417 \mathrm{~cm}^{-1}$, 
$1085 \mathrm{~cm}^{-1}$, and $840 \mathrm{~cm}^{-1}$ are assigned to $\mathrm{CH}_{2}$ bending, $\mathrm{C}-\mathrm{O}$ stretching, and $\mathrm{C}-\mathrm{C}$ stretching, respectively [16,19-23]. The peak at $1141 \mathrm{~cm}^{-1}$ is characteristic of $\mathrm{C}-\mathrm{O}$ bond stretching of the carboxylic groups [16,19-21]. In the $\mathrm{Fe}_{3} \mathrm{O}_{4}$ and $\mathrm{Fe}_{3} \mathrm{O}_{4} / \mathrm{PVA}$ spectra, the absorption peaks in the region of $3400-3000 \mathrm{~cm}^{-1}$ are assigned to the $\mathrm{O}-\mathrm{H}$ stretching of hydroxyl groups [19-21]. The peak at $\sim 1740 \mathrm{~cm}^{-1}$ is attributed to the stretching vibration of C-O. The changes observed in the $\mathrm{Fe}_{3} \mathrm{O}_{4}$ /PVA in comparison with the $\mathrm{Fe}_{3} \mathrm{O}_{4}$ could be attributed to the chemical interactions between the functional groups of the PVA and $\mathrm{Fe}_{3} \mathrm{O}_{4}$.

Figure 4 shows the normalized XRD patterns of the two samples. Normalization of the X-ray diffractograms allows the comparison of different materials, exceeding the limitations related to experimental variables [24]. The diffractograms correspond to cubic $\mathrm{Fe}_{3} \mathrm{O}_{4}$ by comparison with ICDD PDF card no. 01-088-0315, with diffractions peaks (111), (220), (311), (400), (422), (511), (440), (533), and (731). The $\mathrm{Fe}_{3} \mathrm{O}_{4} / \mathrm{PVA}$ composite material presented supplementary diffraction peaks, associated with PVA, at $19.2^{\circ}(2 \theta)$ (a highintensity broad peak), 22.9 (low-intensity shoulder peak), and 40.5 (low-intensity broad peak), corresponding to the diffraction planes (101), (200), and (102), respectively, marked with an asterisk on Figure 4 [25-27]. Alves et al. [28] synthesized the hybrid material of magnetic iron oxide (MOM) with citric acid-doped polyaniline, (PAni(CA)). They reported that a peak of low relative intensity was observed at $2 \theta=25.6^{\circ}$ in the PAni(CA)/MOM hybrid samples. Sanad et al. [29] prepared a magnetic photocatalyst from natural iron ores. They found that the crystallographic planes (220), (311), (400), and (440) of magnetite correspond to $2 \theta=30.5,35.5,43$, and $63^{\circ}$.

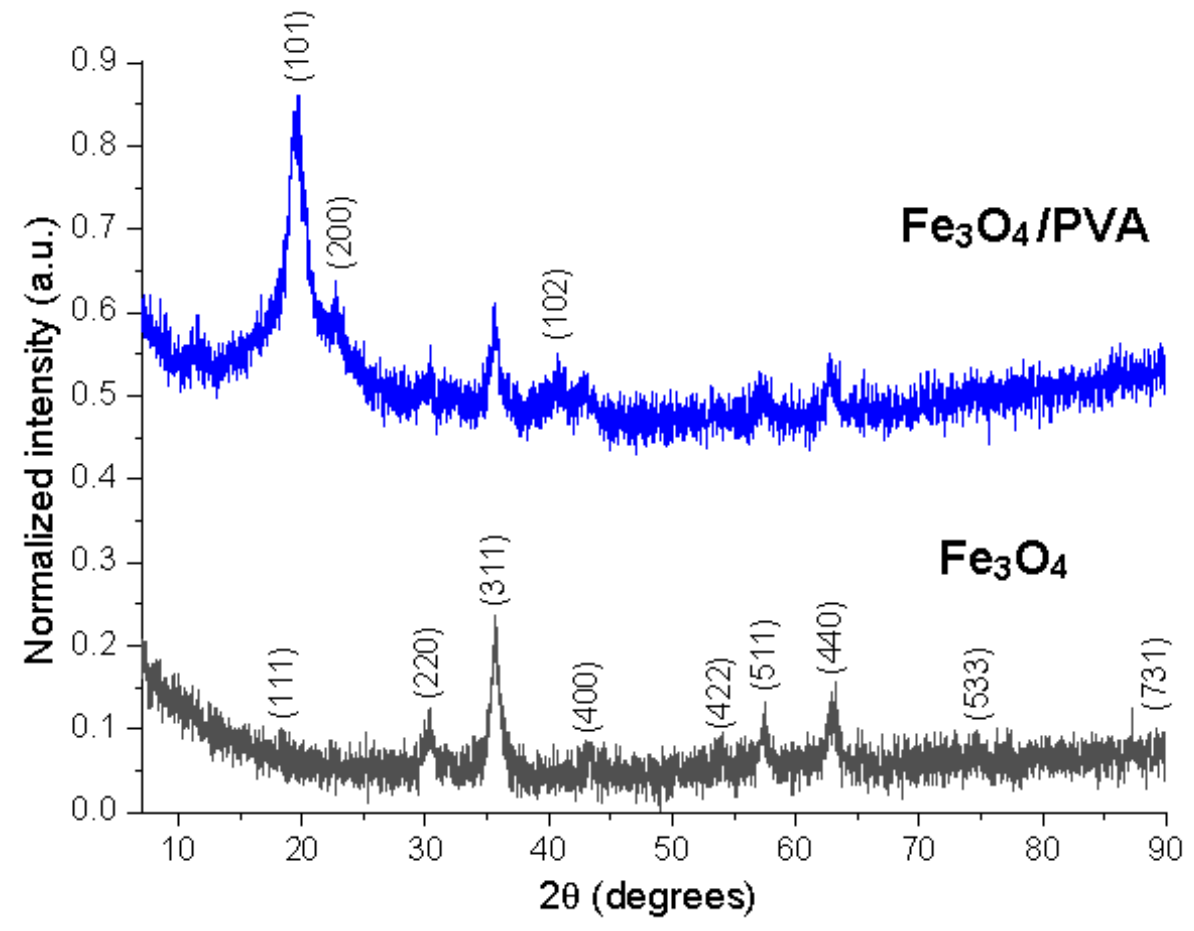

Figure 4. X-ray diffractograms of the $\mathrm{Fe}_{3} \mathrm{O}_{4}$ and $\mathrm{Fe}_{3} \mathrm{O}_{4} / \mathrm{PVA}-$ normalized intensities.

The surface morphology of the prepared magnetite $\left(\mathrm{Fe}_{3} \mathrm{O}_{4}\right)$ and modified magnetite $\left(\mathrm{Fe}_{3} \mathrm{O}_{4} / \mathrm{PVA}\right.$ ) was examined using SEM analysis (magnification $200,000 \times$ ), which is shown in Figure 5.

It can be observed from the SEM images (Figure 5) that the $\mathrm{Fe}_{3} \mathrm{O}_{4}$ presented a nanometric size, with an average size of $9 \mathrm{~nm}$ (Figure 5a). It can also be observed that the $\mathrm{Fe}_{3} \mathrm{O}_{4}$ particles were stabilized by adding PVA to their surface and the $\mathrm{Fe}_{3} \mathrm{O}_{4} /$ PVA particles had a relative diameter of about $11 \mathrm{~nm}$ (Figure $5 \mathrm{~b}$ ). Both types of nanoparticles seemed to be quasi-spherical-shaped $[30,31]$. It was reported in the literature that the small particles can be favorable for the adsorption of dye, and further, this can promote the photocatalytic reaction [8]. 


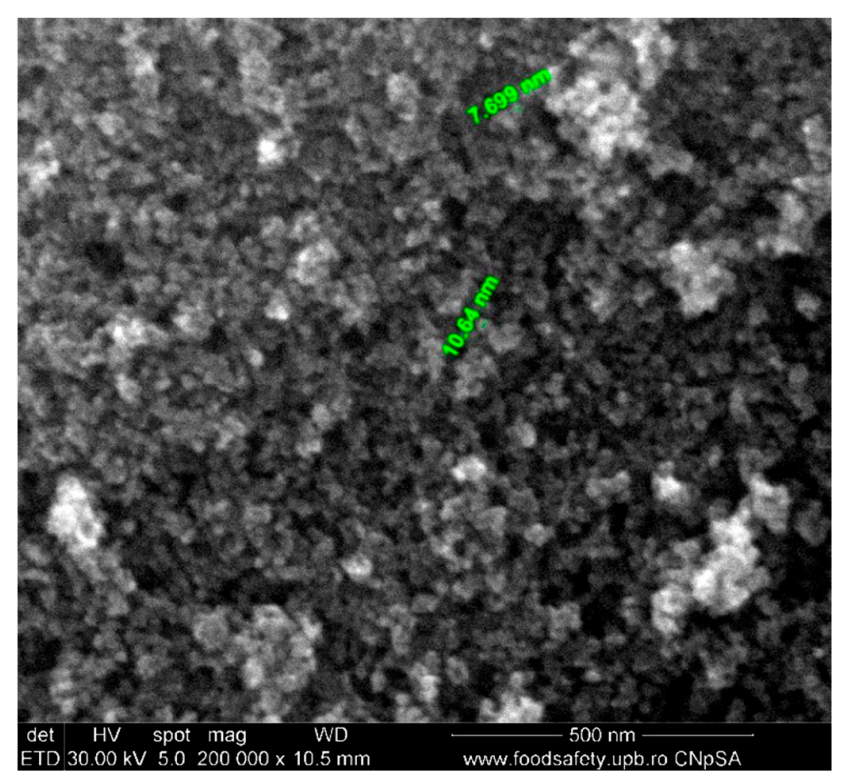

(a)

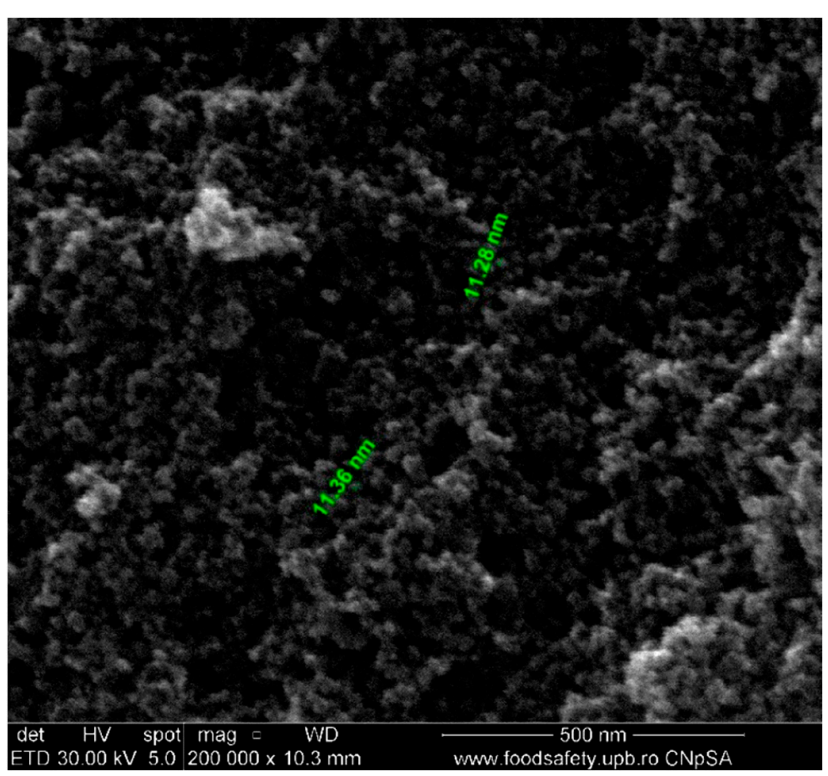

(b)

Figure 5. Scanning electron micrographs of (a) $\mathrm{Fe}_{3} \mathrm{O}_{4}$ and (b) $\mathrm{Fe}_{3} \mathrm{O}_{4} / \mathrm{PVA}$.

\subsection{Photocatalytic Degradation}

The experimental procedure of the photocatalytic tests involved mixing different amounts of the composite $(1.5,2,3$, and $5 \mathrm{~g})$ with $2 \mathrm{~L}$ of aqueous solution of dye with a concentration of $5 \times 10^{-4} \mathrm{~mol} \cdot \mathrm{L}^{-1}$. The mixture was recycled for $120 \mathrm{~min}$ to establish the equilibrium of photocatalysis between the dye and the surface of the composites.

It was established primarily by trial studies on how to decide the initial concentration of the operating solutions and to evolve an experimental scheme in correlation with a series of modifying factors (composite dosage, amount of $\mathrm{H}_{2} \mathrm{O}_{2}, \mathrm{pH}$ ). Based on our preliminary data, a low amount of composite $(<1.5 \mathrm{~g})$ led to a low dye removal percentage.

The dye removal (\%) was calculated using Equation (1) [29,32]:

$$
\text { Dye removal }(\%)=\left(1-\frac{C_{f}}{C_{\text {in }}}\right) \cdot 100,
$$

where: $C_{\text {in }}$-initial concentration of dye $\left(\mathrm{mol} \cdot \mathrm{L}^{-1}\right) ; C_{\mathrm{f}}$-final concentration of dye $\left(\mathrm{mol} \cdot \mathrm{L}^{-1}\right)$.

After each test of the photodegradation, for the calculation of dye removal percentage, the procedure for the determination of the concentration of Methyl Orange from solutions was conducted in triplicate, and the obtained results were presented as means \pm standard deviation. The analysis of concentrations was performed spectrophotometrically at $\lambda=464 \mathrm{~nm}$.

\subsubsection{Effect of Composite Dosage on Dye Removal}

The composite dosage is one of the important factors in the process of the photodegradation of organics because the optimal dosage of composite ensures more active sites and the effective absorption of photons. To investigate the influence of the modified composite dosage $\left(\mathrm{Fe}_{3} \mathrm{O}_{4} /\right.$ PVA) on Methyl Orange removal, a modified composite series of four dosages $(1.5,2,3$, and $5 \mathrm{~g}$ ) was carried out, and the results are presented in Table 1 . To determine the effect of the amount of composite on the removal efficiency of Methyl Orange, a synthetic solution with an initial concentration of Methyl Orange of $5 \times 10^{-4} \mathrm{~mol} \cdot \mathrm{L}^{-1}$, at $\mathrm{pH}$ of 3.0, was used, with an initial amount of $\mathrm{H}_{2} \mathrm{O}_{2}(6.7 \mathrm{~mL})$ and a contact time of $120 \mathrm{~min}$. 
Table 1. Dye removal percentage values for composite at different amounts of composite.

\begin{tabular}{ccc}
\hline \multirow{2}{*}{ Amount of Composite, $\mathrm{g}$} & $\mathrm{Fe}_{3} \mathrm{O}_{4}$ & $\mathrm{Fe}_{3} \mathbf{O}_{\mathbf{4}} / \mathrm{PVA}$ \\
\cline { 2 - 3 } & \multicolumn{2}{c}{ Dye Removal, \% } \\
\hline 1.5 & $65.89 \pm 0.05$ & $78.32 \pm 0.03$ \\
2 & $77.56 \pm 0.07$ & $89.25 \pm 0.04$ \\
3 & $87.71 \pm 0.04$ & $92.54 \pm 0.04$ \\
5 & $91.37 \pm 0.04$ & $98.65 \pm 0.03$ \\
\hline
\end{tabular}

It can be seen from Table 1 that with the increase in the amount of composite, the dye removal percentage value increased gradually. The dye removal percentage was significantly enhanced when the amount of $\mathrm{Fe}_{3} \mathrm{O}_{4} / \mathrm{PVA}$ was increased from 1.5 to $5 \mathrm{~g}$. A higher removal percentage of dye (98.65\%) was obtained for $\mathrm{Fe}_{3} \mathrm{O}_{4} / \mathrm{PVA}(5 \mathrm{~g})$, possibly due to the combination of $\mathrm{Fe}_{3} \mathrm{O}_{4}$ with PVA. The values of dye removal percentage for $\mathrm{Fe}_{3} \mathrm{O}_{4} / \mathrm{PVA}$ were higher in comparison with the values obtained for $\mathrm{Fe}_{3} \mathrm{O}_{4}$, possibly due to the increasing amount of the composite and because the PVA molecules are rich in $\mathrm{OH}^{-}$functional groups. This can lead to an increase in the adsorption sites available on the surface of $\mathrm{Fe}_{3} \mathrm{O}_{4}$ /PVA and the active free radicals such as $\bullet \mathrm{OH}$ generated from the activation of PVA by $\mathrm{Fe}_{3} \mathrm{O}_{4} /$ PVA. Sanad et al. [29] investigated the influence of catalyst (argon-modified banded iron formation ore) dosage for the photocatalytic removal of methylene blue dye. The results showed that the photodegradation efficiencies after $120 \mathrm{~min}$, at $\mathrm{pH}$ of 6.7, were $54.6 \%, 87.5 \%$, and $84.8 \%$ at BIF doses of $0.25,0.5$, and $0.75 \mathrm{~g} \mathrm{~L}^{-1}$, respectively.

\subsubsection{Effect of the Amount of $\mathrm{H}_{2} \mathrm{O}_{2}$}

The concentration of hydrogen peroxide plays a crucial role in deciding the overall efficiency of the degradation process. The effect of the amount of $\mathrm{H}_{2} \mathrm{O}_{2}$ was researched by evaluating the oxidation procedure. The amount of $\mathrm{H}_{2} \mathrm{O}_{2}$ was $3.5,6.7$, and $10 \mathrm{~mL}$. Based on the preliminary data, we observed that the use of a higher excess ( $>10 \mathrm{~mL})$ of $\mathrm{H}_{2} \mathrm{O}_{2}$ was sustained by a large concentration of $\mathrm{H}_{2} \mathrm{O}_{2}$ in the reaction medium, leading to a "scavenger" effect on the $\mathrm{HO} \bullet$ and $\mathrm{HO}_{2} \bullet$ radicals, which expands with the growth in concentration, so the generation of radicals is limited significantly $[8,29]$. During the photocatalytic process, the active species such as hydroxyl radicals ( $\mathrm{HO} \bullet$ radical scavenger), superoxide radical anions $\left(\bullet \mathrm{O}_{2}{ }^{-}\right.$radical scavenger), and holes ( $\mathrm{h}^{+}$radical scavenger) can be consumed by adding $\mathrm{H}_{2} \mathrm{O}_{2}[28,29]$. In this research, an amount of $\mathrm{H}_{2} \mathrm{O}_{2}$ between 3.5 and $10 \mathrm{~mL}$ was used, to avoid the mentioned effects.

The results indicated in Table 2 show that the Methyl Orange photodegradation improved rapidly by increasing the amount of $\mathrm{H}_{2} \mathrm{O}_{2}(6.7 \mathrm{~mL})$ followed by a decrease in photodegradation with a further increment in the amount of $\mathrm{H}_{2} \mathrm{O}_{2}(10 \mathrm{~mL})$. The decreases in dye removal percentage can be explained by the higher amount of $\mathrm{H}_{2} \mathrm{O}_{2}$ resulting in a higher number of absorbed photons [3]. In addition, more photocatalytic sites can be available, leading to an increase in the dye removal percentage. However, care must be taken because the part of hydrogen peroxide not used during the degradation process is inhibited, and therefore, an excess amount is not recommended. It was reported in the literature that the presence of hydrogen peroxide is harmful to many organisms and will significantly affect the overall degradation efficiency if photocatalytic oxidation in the presence of $\mathrm{Fe}_{3} \mathrm{O}_{4}$ is used as a pre-treatment for biological oxidation. A negative effect of hydrogen peroxide is that of capturing the hydroxyl radicals generated. This occurs when large amounts of hydrogen peroxide are used $[3,8]$.

\subsubsection{Effect of $\mathrm{pH}$}

In the photocatalysis process, the $\mathrm{pH}$ of the reaction medium plays a very important role. The effect of $\mathrm{pH}$ on the photodegradation of Methyl Orange in the presence of $\mathrm{Fe}_{3} \mathrm{O}_{4} / \mathrm{PVA}(5 \mathrm{~g})$ at $\mathrm{pH}$ values between 2 and 4 is shown in Figure 6. At different times $(10,20,30,60$, and $120 \mathrm{~min})$, samples were taken once and analyzed to determine the dye removal percentage. The analysis was performed at $\lambda=464 \mathrm{~nm}$. 
Table 2. Dye removal percentage values for composite at different amounts of hydrogen peroxide $\left(\mathrm{H}_{2} \mathrm{O}_{2}\right)$.

\begin{tabular}{ccc}
\hline \multirow{2}{*}{ Amount of $\mathbf{H}_{\mathbf{2}} \mathbf{O}_{2}, \mathbf{m L}$} & $\mathrm{Fe}_{3} \mathrm{O}_{\mathbf{4}}$ & $\mathrm{Fe}_{3} \mathrm{O}_{\mathbf{4}} / \mathrm{PVA}$ \\
\cline { 2 - 3 } & \multicolumn{2}{c}{ Dye Removal, \% } \\
\hline 3.5 & $58.41 \pm 0.06$ & $60.62 \pm 0.04$ \\
6.7 & $71.77 \pm 0.03$ & $80.78 \pm 0.05$ \\
10 & $67.83 \pm 0.04$ & $75.14 \pm 0.06$ \\
\hline
\end{tabular}

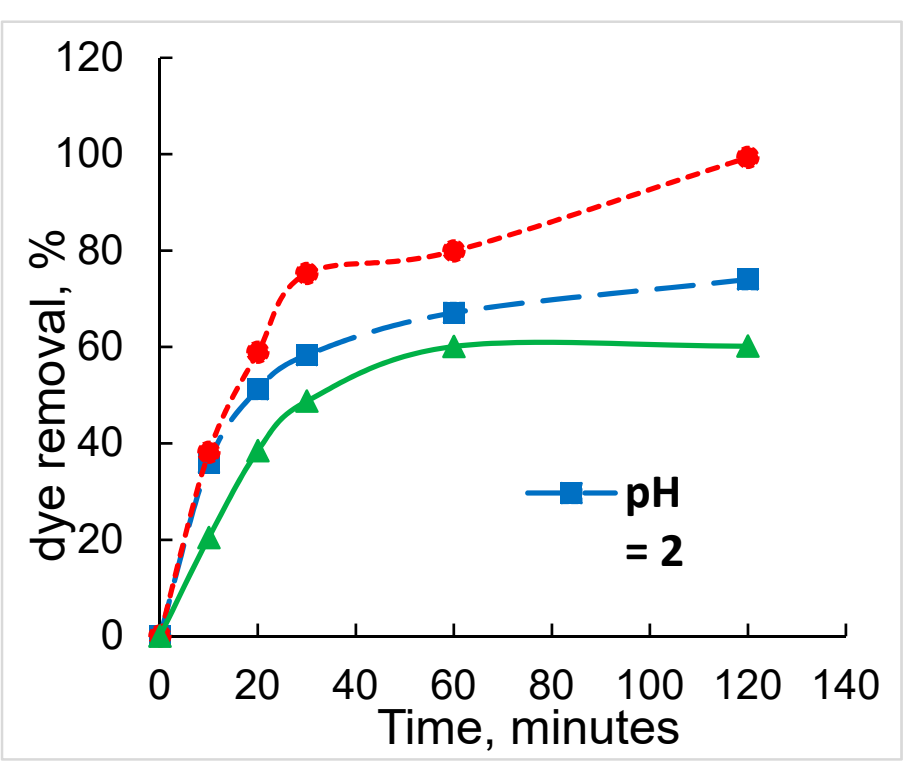

Figure 6. Effect of $\mathrm{pH}$ on the photocatalytic degradation of Methyl Orange under the following conditions: initial dye concentration of $5 \times 10^{-4} \mathrm{~mol} \cdot \mathrm{L}^{-1}$, the concentration of $\mathrm{H}_{2} \mathrm{O}_{2}=30 \%$, and room temperature of $23 \pm 2{ }^{\circ} \mathrm{C}$.

The dye removal efficiency using the $\mathrm{Fe}_{3} \mathrm{O}_{4}$ /PVA catalyst composite, at the initial $\mathrm{pH}$ values of 2,3, and 4, was analyzed (Figure 6). The results showed that a higher dye removal efficiency (99.3\%) occurred at a solution $\mathrm{pH}$ of 3, after a contact time of $120 \mathrm{~min}$.

The estimation of the oxidation in time at distinct initial $\mathrm{pH}$ values is shown in Figure 6. As it is shown, under testing conditions, the degree of oxidation was affected by the initial $\mathrm{pH}$ of the solution, with the maximum estimation being acquired at a $\mathrm{pH}$ of 3. At lower $\mathrm{pH}$ values of the testing solutions $(\mathrm{pH}=2)$, the degree of oxidation is reduced. This can be assigned to the operation of protonation of the molecules of $\mathrm{H}_{2} \mathrm{O}_{2}$ conducting to the formation of oxonium ions, ions that are much steadier toward oxidation, which is not engaging any more in the generation of $\mathrm{HO} \bullet$ and $\mathrm{HO}_{2} \bullet$ radicals active in the oxidation [8,10]. It can be observed from Figure 6 that at values of $\mathrm{pH}$ of 2 and 4 , respectively, dye removal was over $78 \%$ with 120 min of photodegradation in comparison to the photodegradation at $\mathrm{pH}$ of 3 where the dye removal was $99.3 \%$. At $\mathrm{pH}=4$, the level of oxidation decreased in a stronger process owing to the precipitation of the $\mathrm{Fe}^{3+}$ ions to $\mathrm{Fe}(\mathrm{OH})_{3}$ and the development of complexes. The effect of the reaction intermediates is prone to their stability in relation to oxidation and their interaction with the catalytic element. The generation of $\mathrm{HO} \bullet$ and $\mathrm{HO}_{2} \bullet$ radicals is restricted by the vanishing in the solution of the active centers related to the $\mathrm{Fe}^{2+/ 3+}$ ions and the absorption of the UV radiation [8,10,32]. Sanad et al. [29] studied the photocatalytic activity of the modified iron ore obtained by mixing the banded iron formation (BIF) sample with polyvinyl alcohol (PVA). The photocatalytic performance of modified BIF ore samples was examined to degrade the methylene blue (MB) dye at room temperature under UV irradiation. The results indicated that the BIF sample exhibited photocatalytic removals of $85.6 \%, 87.5 \%$, and $74.3 \%$ at $\mathrm{pH} 4, \mathrm{pH} 6.7$, and $\mathrm{pH} 9$ after $120 \mathrm{~min}$, respectively, under UV irradiation. Elmorsi et al. [32] investigated the effect of initial pH. Solutions of Mordant red 73 (MR73) dye 
were irradiated at various initial $\mathrm{pH}(2,3,5$, and 9$)$. The results showed small differences in the degree of decolorization of the dye at different $\mathrm{pH}$ values. For example, in the case of $10 \mathrm{~min}$ reaction times, the decolorization efficiencies were $38.9 \%, 33.5 \%, 37.3 \%$, and $35.4 \%$ at initial $\mathrm{pH}$ values of $2,3,5$, and 9 . At 50 min reaction times, the decolorization efficiencies changed slightly $(94.3 \%, 98.9 \%, 94.5 \%$, and $96.5 \%)$ for initial $\mathrm{pH}$ values of 2,3 , 5 , and 9. The results indicated that MR73 degraded significantly at $\mathrm{pH}=3$, possibly due to the production of the corresponding weak acidic intermediates as a result of degradation and cleavage of the azo group in the dye.

\subsubsection{Effect of the $\mathrm{Fe}_{3} \mathrm{O}_{4} /$ PVA Composite under UV Irradiation}

The effect of UV irradiation on the photodegradation of Methyl Orange in the absence and presence of $\mathrm{Fe}_{3} \mathrm{O}_{4} / \mathrm{PVA}(5 \mathrm{~g})$, at $\mathrm{pH}$ of 3, is shown in Figure 7. At different times (10, $20,30,60,120$, and $150 \mathrm{~min}$ ), samples were taken once and analyzed to determine the removal percentage of Methyl Orange.

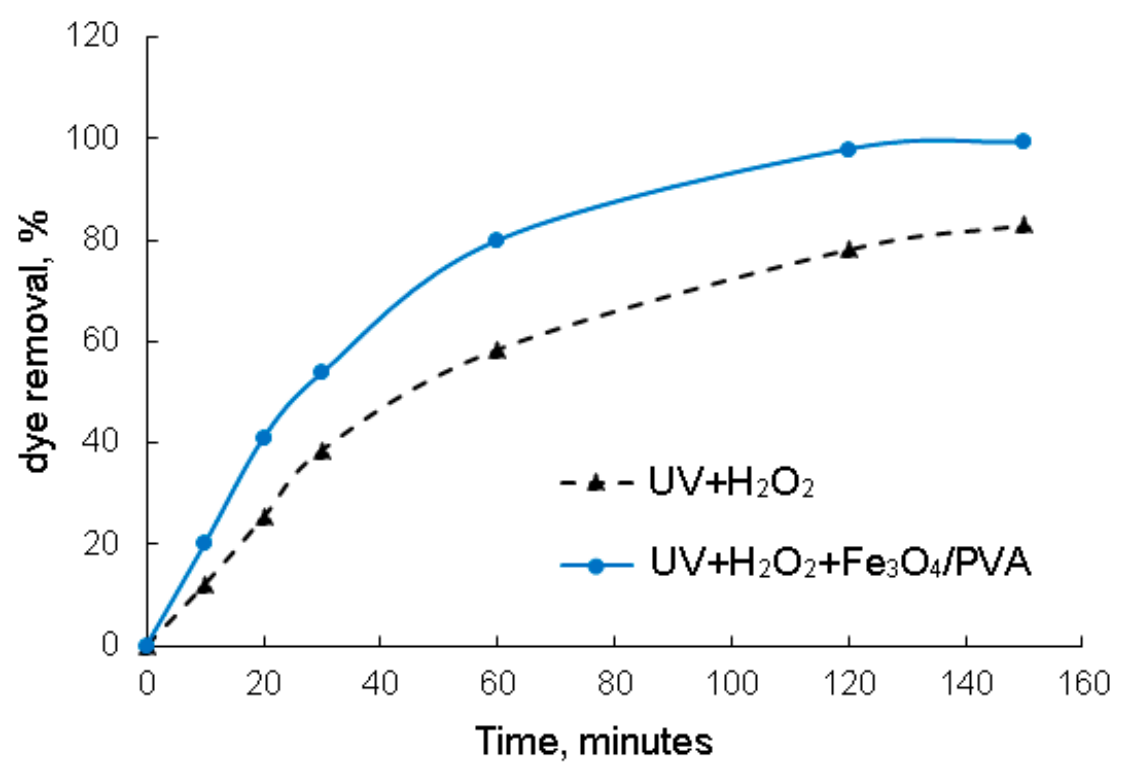

Figure 7. Evaluation of the photodegradation process as a function of the reaction time, at $\mathrm{pH}$ of 3 and initial dye concentration of $5 \times 10^{-4} \mathrm{~mol} \cdot \mathrm{L}^{-1}$.

The tests (UV $+\mathrm{H}_{2} \mathrm{O}_{2}$ vs. $\mathrm{UV}+\mathrm{H}_{2} \mathrm{O}_{2}+\mathrm{Fe}_{3} \mathrm{O}_{4} / \mathrm{PVA}$ ) shown in Figure 7 highlight the relative scarce degradation process $\left(83.05 \%\right.$ in the case of the $\mathrm{UV}+\mathrm{H}_{2} \mathrm{O}_{2}$ process and $99.35 \%$ in the case of $\mathrm{UV}+\mathrm{H}_{2} \mathrm{O}_{2}+\mathrm{Fe}_{3} \mathrm{O}_{4} / \mathrm{PVA}$ ), indicating high stability toward oxidation of the organic compounds present in the wastewater effluent.

From Figure 7, it can be observed that the $\mathrm{Fe}_{3} \mathrm{O}_{4}$ /PVA composite under UV irradiation led to a faster photodegradation of Methyl Orange dye. The removal of dye can be improved from $83.05 \%$ to $99.35 \%$ in $160 \mathrm{~min}$. The presence of PVA in the prepared composite and $\mathrm{H}_{2} \mathrm{O}_{2}$ could accelerate the Methyl Orange degradation to more highly oxidized intermediates in UV light. This fact can indicate that the high dye removal efficiency is completely attributed to the photocatalytic performance of $\mathrm{Fe}_{3} \mathrm{O}_{4} /$ PVA under $\mathrm{UV}+\mathrm{H}_{2} \mathrm{O}_{2}$ [8,32,33]. Alves et al. [28] studied the photodegradation of the methylene blue dye in an aqueous solution under irradiation of ultraviolet light using the hybrids material of magnetic iron oxide (MOM) with citric acid-doped polyaniline (PAni(CA)). The results showed that the high reduction of the dye concentration was $98 \%$ in the presence of PAni(CA)/MOM (mass of aniline:MOM was 2:1). Elmorsi et al. [32] investigated the removal of Mordant red 73 (MR73) azo dye using $\mathrm{H}_{2} \mathrm{O}_{2} / \mathrm{UV}$ and the photo-Fenton reaction. The results indicated that the degradation of MR73 by the $\mathrm{H}_{2} \mathrm{O}_{2} / \mathrm{UV}$ process resulted in a $65 \%$ removal, and by the photo-Fenton reaction $\left(\mathrm{H}_{2} \mathrm{O}_{2} / \mathrm{Fe}^{0} / \mathrm{UV}\right)$, the highest efficiency 
was obtained for the degradation of MR73 dye with disappearance of about $99 \%$ in $15 \mathrm{~min}$, indicating that the dominant decolorization mechanism is the photo-Fenton reaction.

\subsubsection{Photodegradation Mechanism}

Based on the obtained results from the photodegradation experiments of Methyl Orange dye using $\mathrm{Fe}_{3} \mathrm{O}_{4} /$ PVA, the possible mechanism of dye under UV irradiation that can take place is illustrated in Figure 8.

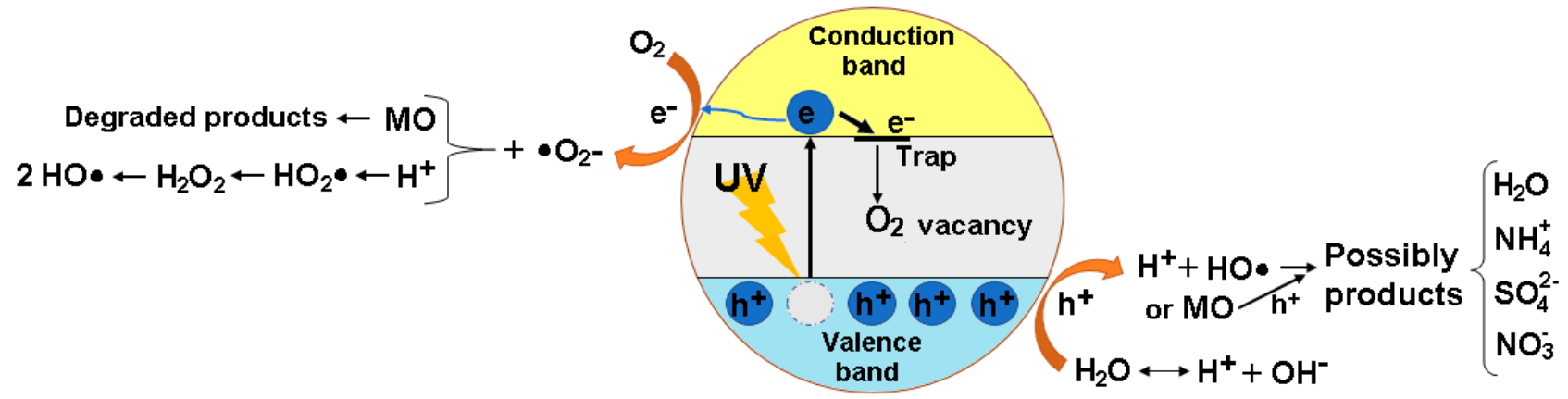

Figure 8. Proposed photodegradation mechanism of $\mathrm{Fe}_{3} \mathrm{O}_{4} /$ PVA composite for the degradation of Methyl Orange (MO) dye.

It can be seen from Figure 8 that the photocatalytic activity depends on the capacity of the $\mathrm{Fe}_{3} \mathrm{O}_{4}$ /PVA composite to create electron-hole pairs. Under UV irradiation, the photons were absorbed by the composite. After that, the electrons $\left(\mathrm{h}^{+}\right)$at the valence band were excited to the conduction band, creating the electron-holes in the valence band. The electron and the hole migrated to the composite surface and took part in the reactions shown in Figure 8. During the photodegradation process, the superoxide radical anions $\left(\bullet \mathrm{O}_{2}{ }^{-}\right)$were generated by the reaction between $\mathrm{O}_{2}$ adsorbed on the surface of the composite and $\mathrm{e}-$. The photogenerated holes can oxidize dye directly. In addition, the photodegradation of the dye can be achieved either using $\mathrm{H}_{2} \mathrm{O}_{2}$ or using $\mathrm{H}_{2} \mathrm{O}$ molecules and $\mathrm{OH}^{-}$groups as electron donors to form free radicals (e.g., hydroxyl radicals: $\mathrm{HO} \bullet$ ) $[3,8,33]$. It was reported in the literature that the $\mathrm{HO} \bullet$ and $\bullet \mathrm{O}_{2}{ }^{-}$are capable of degrading aromatic molecules [34-36].

\section{Conclusions}

In this study, a $\mathrm{Fe}_{3} \mathrm{O}_{4} / \mathrm{PVA}$ composite was successfully synthesized by the precipitation process to degrade Methyl Orange using a laboratory photocatalytic reactor.

The FTIR spectra showed that the PVA was successfully added onto the $\mathrm{Fe}_{3} \mathrm{O}_{4}$ particles' surface; the presence of a peak at $\sim 530 \mathrm{~cm}^{-1}$ in the obtained composites $\left(\mathrm{Fe}_{3} \mathrm{O}_{4}\right.$ and $\mathrm{Fe}_{3} \mathrm{O}_{4}$ /PVA) was assigned to the stretching vibrations of the $\mathrm{Fe}-\mathrm{O}$ bonds. The peaks observed at $1388 \mathrm{~cm}^{-1}\left(\mathrm{Fe}_{3} \mathrm{O}_{4} / \mathrm{PVA}\right)$ and $1324 \mathrm{~cm}^{-1}$ (PVA) were assigned to methylene stretching. The formation of the magnetite phase was definitively confirmed by $\mathrm{XRD}$. The surface morphology showed that the particles had an uneven distribution with different shapes and sizes. The micrographs indicated that the $\mathrm{Fe}_{3} \mathrm{O}_{4}$ particles had been stabilized by adding PVA to their surface and the $\mathrm{Fe}_{3} \mathrm{O}_{4}$ / PVA particles had a relative diameter of about $11 \mathrm{~nm}$.

The photodegradation experiments indicated that the higher Methyl Orange removal efficiency of $98.65 \%$ was obtained for $\mathrm{Fe}_{3} \mathrm{O}_{4} /$ PVA. This higher removal efficiency of the sample indicates that an almost complete decomposition of Methyl Orange occurred. The photodegradation of dye improved rapidly by increasing the amount of $\mathrm{H}_{2} \mathrm{O}_{2}$. The dye removal efficiency of the $\mathrm{Fe}_{3} \mathrm{O}_{4} / \mathrm{PVA}$ was over $78 \%$ with 120 min of photodegradation at values of $\mathrm{pH}$ of 2 and 4 in comparison to the photodegradation at a $\mathrm{pH}$ of 3 where the dye removal was $99.3 \%$.

The chemical and structural properties and high photocatalytic activity of $\mathrm{Fe}_{3} \mathrm{O}_{4} /$ PVA indicated that the prepared composite can also be used in the adsorption or photodegradation processes of other dyes from different wastewater. 
Author Contributions: Conceptualization, C.M., S.C. and V.P.; methodology, C.M., S.C. and A.M.D.; formal analysis, C.M., A.M.D., O.D.O. and A.M.G.; investigation, C.M., V.P., A.M.G., V.R. and R.C.F.; data curation, S.C., A.M.D., O.D.O. and A.M.G.; writing-original draft preparation, C.M., S.C. and V.P.; writing-review and editing, C.M., S.C., V.P., R.C.F. and A.M.G. All authors have read and agreed to the published version of the manuscript.

Funding: This research was funded by the University POLITEHNICA of Bucharest, through the UPBGEX 2017, Project No. 178/25.09.2017 and financial support of the Romanian Ministry of Research and Innovation MCI (Ministry of Research, Innovation and Digitization-MCID) through INCDCP ICECHIM Bucharest 2019-2022 Core Program PN. 19.23-Chem-Ergent, Project No.19.23.03.

Institutional Review Board Statement: Not applicable.

Informed Consent Statement: Not applicable.

Data Availability Statement: Not applicable.

Conflicts of Interest: The authors declare no conflict of interest.

\section{References}

1. Chiu, Y.-H.; Chang, T.-F.M.; Chen, C.-Y.; Sone, M.; Hsu, Y.-J. Mechanistic Insights into Photodegradation of Organic Dyes Using Heterostructure Photocatalysts. Catalysts 2019, 9, 430. [CrossRef]

2. Xu, L.; Zhang, X.; Hana, J.; Gong, H.; Meng, L.; Mei, X.; Sun, Y.; Qi, L.; Gan, L. Degradation of emerging contaminants by sono-Fenton process with in situ generated $\mathrm{H}_{2} \mathrm{O}_{2}$ and the improvement by P25-mediated visible light irradiation. J. Hazard. Mater. 2020, 391, 122229. [CrossRef]

3. Golshan, M.; Zare, M.; Goudarzi, G.; Abtahi, M.; Babaei, A.A. $\mathrm{Fe}_{3} \mathrm{O}_{4} @ H A P-e n h a n c e d$ photocatalytic degradation of Acid Red73 in aqueous suspension: Optimization, kinetic, and mechanism studies. Mater. Res. Bull. 2017, 91, 59-67. [CrossRef]

4. Salim, S.; Hadibarata, T.; Elwina, E.; Dewi, R.; Alaraidh, I.A.; Al-Ghamdi, A.A.; Alsahli, A.A. Development of activated carbon from Eichhornia Crassipes via chemical activation and its application to remove a synthetic dye. Biointerface Res. Appl. Chem. 2019, 9, 4394-4400.

5. Ali, S.F.A.; Gad, E.S. Investigation of an adsorbent based on novel starch/chitosan nanocomposite in extraction of indigo carmine dye from aqueous solutions. Biointerface Res. Appl. Chem. 2020, 10, 5556-5563.

6. Gangarajula, Y.; Kedharnath, R.; Gopal, B. Investigation of photocatalytic activity of pure strontium hydroxyapatite and its Ti-substituted and TiO2 loaded forms. Appl. Catal. A Gen. 2015, 506, 100-108. [CrossRef]

7. Ma, J.; Yu, F.; Zhou, L.; Jin, L.; Yang, M.; Luan, J.; Tang, Y.; Fan, H.; Yuan, Z.; Chen, J. Enhanced adsorptive removal of methyl orange and methylene blue from aqueous solution by alkali-activated multiwalled carbon nanotubes. ACS Appl. Mater. Interfaces 2012, 4, 5749-5760. [CrossRef]

8. Chen, H.; Chen, N.; Gao, Y.; Feng, C. Photocatalytic degradation of methylene blue by magnetically recoverable $\mathrm{Fe}_{3} \mathrm{O}_{4} / \mathrm{Ag}_{6} \mathrm{Si}_{2} \mathrm{O}_{7}$ under simulated visible light. Powder Technol. 2018, 326, 247-254. [CrossRef]

9. Xu, L.; Meng, L.; Zhang, X.; Mei, X.; Guo, X.; Li, W.; Wang, P.; Gan, L. Promoting Fe $\mathrm{Fe}^{3+} / \mathrm{Fe}^{2+}$ cycling under visible light by synergistic interactions between P25 and small amount of Fenton reagents. J. Hazard. Mater. 2019, 379, 120795. [CrossRef]

10. De Oliveira Guidolin, T.; Possolli, N.M.; Polla, M.B.; Wermuth, T.B.; Franco de Oliveira, T.; Eller, S.; Montedo, O.R.K.; Arcaro, S.; Cechinel, M.A.P. Photocatalytic pathway on the degradation of methylene blue from aqueous solutions using magnetite nanoparticles. J. Clean. Prod. 2021, 318, 128556. [CrossRef]

11. Rivera, F.L.; Recio, F.J.; Palomares, F.J.; Sánchez-Marcos, J.; Menéndez, N.; Mazarío, E.; Herrasti, P. 2020. Fenton-like degradation enhancement of methylene blue dye with magnetic heating induction. J. Electroanal. Chem. 2020, 879, 114773. [CrossRef]

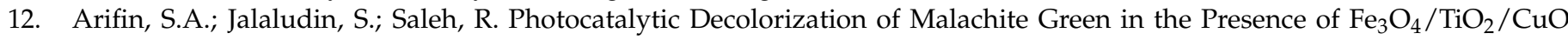
Nanocomposites. Mater. Sci. Forum 2015, 1123, 264-269.

13. Liu, X.; Zhang, T.; Xu, D.; Zhang, L. Microwave-Assisted Catalytic Degradation of Crystal Violet with Barium Ferrite Nanomaterial. Ind. Eng. Chem. Res. 2016, 55, 11869-11877. [CrossRef]

14. Mahmoudi, M.; Simchi, A.; Imani, M.; Stroeve, P.; Sohrabi, A. Templated growth of superparamagnetic iron oxide nanoparticles by temperature programming in the presence of poly (vinyl alcohol). Thin Solid Films 2010, 518, 4281-4289. [CrossRef]

15. Seo, K.; Sinha, K.; Novitskaya, E.; Graeve, O.A. Polyvinylpyrrolidone (PVP) effects on iron oxide nanoparticle formation. Mater. Lett. 2018, 215, 203-206. [CrossRef]

16. Usawattanakul, N.; Torgbo, S.; Sukyai, P.; Khantayanuwong, S.; Puangsin, B.; Srichola, P. Development of Nanocomposite Film Comprising of Polyvinyl Alcohol (PVA) Incorporated with Bacterial Cellulose Nanocrystals and Magnetite Nanoparticles. Polymers 2021, 13, 1778. [CrossRef]

17. Gulgun, M.A.; Nguyen, M.H.; Kriven, W.M. Polymerized organic-inorganic synthesis of mixed oxides. J. Am. Ceram. Soc. 1999, 82, 556. [CrossRef]

18. Stoia, M.; Istratie, R.; Păcurariu, C. Investigation of magnetite nanoparticles stability in air by thermal analysis and FTIR spectroscopy. J. Therm. Anal. Calorim. 2016, 125, 1185-1198. [CrossRef] 
19. Orbulet, O.D.; Borda, C.; Garleanu, D.; Garleanu, G.; Stancu, A.; Modrogan, C. $\mathrm{Fe}_{3} \mathrm{O}_{4}$ particles functionalized with EDTA and PVA-Preparation, characterization and their use in removal of manganese ions from synthetic aqueous solutions. UPB Sci. Bull. Ser. B 2021, 83, 101-116.

20. Adak, A.K.; Pathak, A.; Pramanik, P. Polyvinyl alcohol evaporation method for preparation of submicron chromite powders. Br. Ceram. Trans. 1999, 98, 200. [CrossRef]

21. Mansur, H.S.; Sadahira, C.M.; Souza, A.N.; Mansur, A.A.P. FTIR spectroscopy characterization of poly (vinyl alcohol) hydrogel with different hydrolysis degree and chemically crosslinked with glutaraldehyde. Mater. Sci. Eng. C 2008, 28, 539. [CrossRef]

22. Galinato, M.G.I.; Whaley, C.M.; Lehnert, N. Vibrational Analysis of the Model Complex ( $\mu$-edt) $\left[\mathrm{Fe}(\mathrm{CO})_{3}\right]_{2}$ and Comparison to Iron-only Hydrogenase: The Activation Scale of Hydrogenase Model Systems. Inorg. Chem. 2010, 49, 3201. [CrossRef]

23. Stoia, M.; Pacurariu, C.; Istratie, R.; Niznansky, D. Solvothermal synthesis of magnetic $\mathrm{Fe}_{\mathrm{x}} \mathrm{O}_{\mathrm{y}} / \mathrm{C}$ nanocomposites used as adsorbents for the removal of methylene blue from wastewater. J. Therm. Anal. Calorim. 2015, 121, 989. [CrossRef]

24. Fierascu, R.C.; Fierascu, I.; Lungulescu, E.M.; Nicula, N.; Somoghi, R.; Ditu, L.M.; Ungureanu, C.; Sutan, A.N.; Draghiceanu, O.A.; Paunescu, A.; et al. Phytosynthesis and radiation-assisted methods for obtaining metal nanoparticles. J. Mater. Sci. 2020, 55 1915-1932. [CrossRef]

25. Chen, Y.-N.; Jiao, C.; Zhao, Y.; Zhang, J.; Wang, H. Self-Assembled Polyvinyl Alcohol-Tannic Acid Hydrogels with Diverse Microstructures and Good Mechanical Properties. ACS Omega 2018, 3, 11788-11795. [CrossRef]

26. Aziz, W.N.A.; Bumajdad, A.; Sagheer, F.A.; Madkour, M. Selective synthesis and characterization of iron oxide nanoparticles via PVA/PVP polymer blend as structure-directing agent. Mater. Chem. Phys. 2020, 249, 122927. [CrossRef]

27. Nigam, B.; Mittal, S.; Prakash, A.; Satsangi, S.; Mahto, P.K.; Swain, B.P. Synthesis and characterization of $\mathrm{Fe}_{3} \mathrm{O}_{4}$ nanoparticles for nanofluid applications-A review. IOP Conf. Ser. Mater. Sci. Eng. 2018, 377, 012187. [CrossRef]

28. de Alves, F.H.O.; Araújo, O.A.; de Oliveira, A.C.; Garg, V.K. Preparation and characterization of PAni(CA)/Magnetic iron oxide hybrids and evaluation in adsorption/photodegradation of blue methylene dye. Surf. Interfaces 2021, 23, 100954. [CrossRef]

29. Sanad, M.M.S.; Farahat, M.M.; El-Hout, S.I.; El-Sheikh, S.M. Preparation and characterization of magnetic photocatalyst from the banded iron formation for effective photodegradation of methylene blue under UV and visible illumination. J. Environ. Chem. Eng. 2021, 9, 105127. [CrossRef]

30. Oliveira, P.N.; Bini, R.D.; Dias, G.S.; Alcouffe, P.; Santos, I.A.; David, L.; Cótica, L.F. Magnetite nanoparticles with controlled sizes via thermal degradation of optimized PVA/Fe(III) complexes. J. Magn. Magn. Mater. 2018, 460, 381-390. [CrossRef]

31. Jia, H.; Huang, F.; Gao, Z.; Zhong, C.; Zhou, H.; Jiang, M.; Wei, P. Immobilization of v-transaminase by magnetic PVA-Fe ${ }_{3} \mathrm{O}_{4}$ nanoparticles. Biotechnol. Rep. 2016, 10, 49-55. [CrossRef] [PubMed]

32. Elmorsi, Y.M.; Riyad, Z.H.; Mohamed, H.M.; Abid, H.; Bary, E. Decolorization of mordant red 73 azo dye in water using $\mathrm{H}_{2} \mathrm{O}_{2} / \mathrm{UV}$ photo Fenton treatment. J. Hazard. Mater. 2010, 174, 352-356. [CrossRef] [PubMed]

33. Liu, W.; Qian, G.M.; Zhang, B.; Liu, L.L.; Liu, H. Facile synthesis of spherical nanohydroxyapatite and its application in photocatalytic degradation of methyl orange dye under UV irradiation. Mater. Lett. 2016, 178, 15-17. [CrossRef]

34. Ummartyotin, S.; Manuspiya, H. A critical review of eggshell waste: An effective source of hydroxyapatite as photocatalyst. J. Met. Mater. Miner. 2018, 28, 124-135.

35. Chai, Y.; Ding, J.; Wang, L.; Liu, Q.; Ren, J.; Dai, W.-L. Enormous enhancement in photocatalytic performance of $\mathrm{Ag}_{3} \mathrm{PO}_{4} / \mathrm{HAp}$ composite: A Z-scheme mechanism insight. Appl. Catal. B Environ. 2015, 179, 29-36. [CrossRef]

36. Da Silva, C.G.; Faria, J.L. Photochemical and photocatalytic degradation ofan azo dye in aqueous solution by UV irradiation. J. Photochem. Photobiol. A Chem. 2003, 155, 133-143. [CrossRef] 